MATEC Web of Conferences 22,01064 (2015)

DOI: $10.1051 /$ matecconf/ 20152201064

C Owned by the authors, published by EDP Sciences, 2015

\title{
A Study on the Spread Spectrum Steganography Based on the High-order Markov Model
}

Kaicheng $\mathrm{Wu}^{1,2}$

${ }^{1}$ School of Computer Science, Wuhan University, Wuhan, Hubei, China

${ }^{2}$ School of Mathematics and Computer Science, Jianghan University, Wuhan, Hubei, China

This article has been withdrawn by the authors.

Request approved by the editors and the publisher on September 1st, 2015.

This is an Open Access article distributed under the terms of the Creative Commons Attribution License 4.0, which permits unrestricted use, distribution, and reproduction in any medium, provided the original work is properly cited. 